\title{
Stop the Spread: Gossip, COVID-19, and the Theology of Social Life
}

\author{
Sam Shuman (D)
}

Citation: Shuman, Sam. 2021. Stop the Spread: Gossip, COVID-19, and the Theology of Social Life. Religions 12: 1037. https://doi.org/10.3390/rel 12121037

Academic Editors: Roberta Ricucci and Solange Lefebvre

Received: 25 August 2021

Accepted: 16 November 2021

Published: 24 November 2021

Publisher's Note: MDPI stays neutral with regard to jurisdictional claims in published maps and institutional affiliations.

Copyright: (C) 2021 by the author. Licensee MDPI, Basel, Switzerland. This article is an open access article distributed under the terms and conditions of the Creative Commons Attribution (CC BY) license (https:// creativecommons.org/licenses/by/ $4.0 /)$.
Center for Jewish Studies, Fordham University, New York, NY 10023, USA; sshuman2@fordham.edu

\begin{abstract}
Scholars, journalists, and activists alike have offered a variety of explanations to understand the high incidence of COVID-19 among Haredi Jewish communities in the United States and abroad. Despite their differences, each assumes that Haredi Jews are inherently collectivistic. This article challenges this assumption and contends that COVID-19 has amplified pre-existing anxieties about the lack of proper social cohesion and solidarity within Haredi Jewish communities. It analyzes these dynamics through "Stop the Spread", a Haredi "anti-gossip" campaign that links the ill health of social relations within the Haredi Jewish body politic to the spread of SARS-CoV-2 within its communities.
\end{abstract}

Keywords: gossip; COVID-19; Haredi Jews; theology; solidarity; political economy of language

\section{Introduction}

Segments of men within Haredi Jewish communities, ${ }^{1}$ both within the United States and abroad, continue to congregate as SARS-CoV-2 spreads-sometimes clandestinely to pray in synagogues and sometimes visibly in the public square to mourn the deaths of rabbinic leaders. This has raised concerns given the high number of reported COVID-19 cases among Haredi Jews in Brooklyn neighborhoods like Boro Park and Williamsburg. In October 2020, New York governor, Andrew Cuomo, issued a targeted "cluster action", which imposed stricter lockdown orders for "red zones" in New York. These red zones house significant Haredi Jewish communities and required them to close their schools, non-essential businesses, and places of worship. The order limited gatherings to no more than 10 people and charged violators with $\$ 15,000$ fines (Palmer 2020). In response, protests broke out. On 7 October, hundreds of men took to the streets of Boro Park to dance and burn masks while chanting "Jewish Lives Matter".

Prior to this incident, a steady stream of commentary emerged to explain the reasons why some Haredi Jews may not be adhering to prescribed social distancing guidelines. A series of arguments and counterarguments formed. One side argued that the "antiscientific", anti-modern, and ignorant nature of Haredim drove them to such reckless behavior (Greenberg 2020). Groupthink, anti-individualism, and unflinching allegiance to rabbinic authorities are blamed as the familiar culprits. Another side formed in response, one that explains the collective structures and rituals that govern Haredi life. This side proclaims that Haredim are not ignorant or guilty of false consciousness (Avishai et al. 2020; Goldberger 2020). COVID-19 has upended their everyday lives, a lifeworld structured around face-to-face rituals and communal gatherings. This side argues that one must attend to the local logics of everyday life to really understand what outsiders crudely castigate as reckless or ignorant behavior. Extended ethnographic fieldwork and firsthand accounts are summoned as evidence to demonstrate expertise and authority. These opinions accord with an anthropological sensibility to estrange the familiar and to familiarize the strange. As incisively noted by Jonathan Mair, Ann H. Kelly, and Casey High in the introduction to their edited volume on the Anthropology of Ignorance: "by recognizing the culture of the so-called primitive, the native, or subaltern as legitimate material for the generation of 
academic knowledge in this way, anthropologists have often set out to defend the people they study - showing that far from being ignorant, they are actually very knowledgeable indeed" (High et al. 2012). Other critics have framed Haredi behaviors during COVID-19 in a broader and more comparative framework by attending to the "politics of accusation" (Hughes et al. 2019) —how particular racial and religious bodies, when assembled into crowds, become easily marked as the vectors of contagion. Anthropologists Michal KravelTovi and Esra Özyürek provide the reader with a list of sites across the globe in which secular states castigate (minority) religious communities. As they compellingly argue:

In all of these cases, the epidemiological and scientific discourses seem to intersect with social stereotypes, xenophobic hostility, and a discourse of suspicion directed towards foreigners and minority groups as being dangerous and possibly uncontainable populations. These anxious articulations conflate medical uncertainty with moral panic; the danger of contagion with the threat of symbolic pollution; biological risks to public health with threats to the social and political order (Kravel-Tovi and Özyürek 2020).

Yet each side of the debate relies upon the same underlying assumption to argue its case: Haredi communities (and other similar communities) operate cohesively as a social whole or unit. ${ }^{2}$ They confuse a utopian and normative ideal with the sticky ethical realities, frictions, and contingencies of everyday life within them. Internal unity and cohesion, which paper over internal divisions, may be projected to outsiders to secure political rights, economic security, and educational autonomy. This form of "strategic essentialism" (Spivak 1993) can be easily misrecognized. Historians and social scientists have only further occluded internal difference within Haredi communities by reproducing a "billiard ball" model of society (Wolf 1982) in their texts. They describe Haredi communities as isolated and bounded "islands" (Rubin 1972) and "enclaves" (Mintz 1998). "Ethnic enclaves" do not simply exist "in a pre-given world of separate and discrete 'peoples and cultures'" (Gupta and Ferguson 1992); they are discursively made and reproduced. As with the Western concept of "Chinatown", Haredi "enclaves" reveal how "racial ideology has been materially embedded in space ... and it is through 'place' that it has been given a local referent, become a social fact, and aided in its own reproduction" (Anderson 1987).

Neither are these communities immune to an ethos of individualism, which treats collectivism as the enemy of self-actualization. To represent Haredi worlds as collectivistic in all domains of life, as if structured by mystical, unbreakable bonds of mechanical solidarity (Durkheim et al. 2014), is to elide the unruly and messy contingencies of everyday life under an impossible, ethical ideal (Laidlaw 1995). I explore the significance of why and how different global Haredim are policing gossip in this historical moment. I center the analysis on "Stop the Spread", a Haredi "anti-gossip" campaign that links the ill health of social relations within the Haredi Jewish body politic to the spread of SARS-CoV-2 within their communities.

Classical anthropological literature on gossip largely concerns itself with debates about the social utility and function of gossip. In Gluckman's classic "Gossip and Scandal", he argued that gossip maintains social bonds, reinforces group norms, conceals aggression, and informally evaluates a leader for selection (Gluckman 1963). ${ }^{3}$ Other anthropologists, particularly among transactionalist theorists, refuted this approach and argued that gossip operated as a form of "information management" to be manipulated by individuals for the purposes of advancing their own self-interests (Paine 1967). I follow subsequent anthropologists, who argued that this "debate" between Gluckman (who offered a dialectical approach to structural-functionalism) and the transactionalists (who fell prey to methodological individualism) can be easily resolved, "as gossip can have both cohesionbuilding and self-serving purposes or consequences" (Besnier 2009). I am more interested in analyzing gossip as a metadiscursive object-how gossip itself becomes an object of religious-ethical discourse, one that can be explicitly labelled, monitored, and policed. While normative theorists of gossip contend that "gossip is inevitably confined to a group and kept from outsiders", (Merry 1984) I ask what unfolds when everyday communal gossip is leaked to outsiders. 
I first situate this media campaign within a particular Jewish genealogy centered on ethical cultivation. I then argue that this anti-gossip media campaign should be contextualized within a broader campaign to police speech. In this moment, Haredi whistleblowers are leaking information about illicit gatherings to governmental officials and leaders are fortressing their institutions against unwelcome inspections through apotropaic magic.

\section{Corona Cosmology}

In late March 2020, an advertisement entitled "Stop the Spread" appeared on my Facebook newsfeed. Intrigued, I clicked on the website: https: / /www.stopthespread.com/ (accessed on 26 March 2020). Suddenly, the real meaning behind the campaign slogan was revealed to me: "Negativity is a virus. Join the movement not to text, forward or post anything hurtful to others for 14 days as a merit to protect us from the Coronavirus crisis and to help bring the Geulah Shelaima [the complete redemption]".

A Facebook advertising algorithm had found me. My research about Hasidic Jews made me the target audience for a Jewish anti-gossip campaign. Packaging itself in the aesthetics of a late capitalist advertising campaign, in which consumers are enticed with promotional offers of 14-day free trials, the campaign invites viewers to "Join now" and "Start Your 14 Days Today". Participants may elect to display their name on the website itself, in a scrolling text that lists the names of the 6872 participants who have already taken the pledge. Of course, making a pledge warrants the risk of making a promise one might break, which violates Jewish law (halacha). The everyday, secular e-contract, typically signified with a short text and an opt-in checkbox, had to be amended: "By joining, I accept, Bli Neder (without avowing), to not text, forward or post anything hurtful to others via any electronic means for 14 days, as a merit to protect us from the COVID-19 Coronavirus and to help bring the Geulah Shelaima" (italics added for emphasis). ${ }^{4}$

While only the pledge is required to participate, participants may also elect to receive regular reminders to strengthen their resolve (as one might expect from a weight loss or fitness app). One can elect to receive reminders via text message, WhatsApp, and/or email. As a participant, I chose the e-mail option. Over the course of two weeks, I received seven e-mails. The last e-mail included a sample of two laws from Guard Your Tongue, a holy book written by Rabbi Zelig Pliskin, a noted rabbi and psychologist. As explained in the previous email, this sample was in accordance with the advice of rabbinic leaders, who had recommended that each Jew learn the laws about Shmiras HaLashon (Guarding One's Speech) during the COVID-19 epidemic. The daily digest included the first lessons from Pliskin's book. The first lesson outlined the distinction between true derogatory statements (lashon hara) and false derogatory statements (motzi shaim ra), both of which violate Jewish law. While the latter is a greater offense, the former is more disarming. Those who spread lashon hara can easily dupe themselves into believing that it is permissible precisely because the statements are true. The second lesson argues that all Jews must know the laws of lashon hara as intimately as a slaughterer who regularly reviews the Jewish laws of shechita (slaughter). By replying to the last e-mail, one could then subscribe to receive future e-mails with daily laws excerpted from Pliskin's book.

At the outset of the pandemic, two global leaders of Haredi Jewry, Rabbis Chaim Kanievsky and Gershon Edelstein, proclaimed in a letter that Jews could protect themselves from contracting the disease by stopping the spread of gossip (Hoffman 2020). What does one make of these pronouncements and media campaigns? Why has gossip become their clarion call? What does this reveal about the everyday social lives and anxieties of its intended audience? And why might the spread of gossip resonate, to an even greater degree, at this moment of crisis?

This campaign must be situated within a broader historical, moral crusade to contain the spread of gossip among religious Jewish publics. Ancient Jewish texts indicate the severity of gossip. In a famous Talmudic passage (Arakhin 15b), gossip becomes likened to murder itself: 
In the West, Eretz Yisrael [the land of Israel], they say: Third speech, i.e., malicious speech about a third party, kills three people. It kills the one who speaks malicious speech, and the one who accepts the malicious speech when he hears it, and the one about whom the malicious speech is said. Rabbi Hama, son of Rabbi Hanina, says: What is the meaning of that which is written: "Death and life are in the hand of the tongue" (Proverbs 18:21). Does the tongue have a hand? Rather the verse comes to tell you that just as a hand can kill, so too a tongue can kill. If you were to claim that just as the hand kills only from close by, so too the tongue kills only from close by, therefore the verse states: "Their tongue is a sharpened arrow" (Jeremiah 9:7). The tongue kills like an arrow that is fired from a bow, at a great distance (Steinsaltz 2019).

In the modern era, gossip (and other prohibited speech-acts) became most intimately tied to the work and personage of Rabbi Yisroel Meir Kagan (1838-1933) or The Chofetz Chaim. The moral crusade associated with him today is associated with lashon hara ("evil speech", lit: "evil tongue"), the spreading of truthful speech or gossip, which often becomes bundled with broader speech-act prohibitions. ${ }^{5}$ The Chofetz Chaim Heritage Foundation continues to operate today, releasing materials used to cultivate a proper Jewish bildung or "moral education (khinekh)" in each child (Fader 2009). A slew of children's chants and songs accompany this campaign, their playful rhyming scheme in ironic tension with the seriousness of its message. On the playground of the Orthodox Jewish school I attended as a child, we would chant, "'Lashon hara, lamed hey [the initial Hebrew letters of lashon hara]: Go to hell the easy way!' Often, however, this goes hand in hand with a rejoinder: Lashon hara, lamed hey: Tell it to me anyway!" (Lewis 2015). ${ }^{6}$

Similar campaigns have been adopted by other Haredi publics, often foisting the burden upon women to maintain "purity" for the sake of the religious body politic. In Lakewood, New Jersey, an English message on WhatsApp circulated with the recording of a prominent rabbi imploring women to be more modest with their wig selection. In Bnei Brak, Israel, a Hebrew poster connected the numerology (gematria) of the letters in the Hebrew words for "Corona virus" to "lack of modesty". In yet another example, one of the rebbes of the Satmar Hasidic dynasty implored his Hasidic followers in the gated community of Kiryas Yoel in a Yiddish poster:

When Klal Yisroel [the Jewish people] finds itself in a time of suffering, it's a sign from Hashem [God] that we need to examine our ways, because He doesn't send ills without sins to warrant it. And I want to specifically talk to women about tznius [modesty] ... if we will change this, Hashem will be able to come back and dwell among us and will cure us from all sickness. If only we dress according to tradition: shaved heads, short sheitel [wig], fully covered with a hat, no makeup, long sleeves (Jaskoll 2020).

Images, words, and bodies have become more visibly censored and policed, often overdetermining and metaphorizing the woman's body as the body of the Jewish nation. To maintain the integrity of the body politic, her body becomes a site of surveillance. And so it is not altogether surprising that in this moment, other sites of bodily exposure should become targeted sites of religious regulation, too: sites of purity and danger (Douglas 1966) that open to the world; orifices like mouths (that can gossip) and ears (that can receive it).

The campaign also clearly fits within an extant cosmological framework that associates impurity, illness, and quarantine with gossip. As the campaign materials explain: "many have also pointed out the similarity between the mandated 14-day quarantine and the Torah enforced 14-day period that a Metzorah (caused by speaking negatively) must stay in quarantine". This references the biblical laws outlined in the Book of Leviticus about a Metzorah, a person afflicted with a skin disease (often mistranslated as "leprosy") for speaking gossip, who must quarantine herself from the rest of the community for 14 days. Rather than presenting its message within a punitive framework, however, the campaign takes a positive spin: by avoiding gossip Jews can accumulate merit (zchus) that can ward off the pandemic. This mechanism will not stop the spread of SARS-CoV-2 across the globe; rather, it aims to protect the bounded "world" of the faithful. 
The anti-gossip campaign emerges at a particular moment in which certain members of Haredi communities are trying to contain community members from leaking "gossip" to governmental authorities, which conduct raids on illegal gatherings. In Antwerp, Belgium, a lawyer and professor, Henri Rosenberg, broadcasts a regular "CoronaVirus Update" (Figure 1) across Facebook and WhatsApp social media platforms (he then sends these updates to enforcement authorities before violations occur). Dedicated to the memory of Antwerp's previous Haredi Chief Rabbi, Rabbi Chaim Kreiswirth, these updates are distributed under the auspices of Rosenberg's non-profit organization (vzw), "GoedKosjerJoodse Verbruikersvereniging" or "GoedKosjer-Jewish Consumer Defense Association", which has been registered in Belgium as a consulting firm since 1989. Each update includes a disclaimer at the bottom: "information often based on rumors. Updates and precisions [sic] welcome". In these updates, Rosenberg reports information about the location of weddings occurring in Antwerp and abroad, including: the unmasked presence of Antwerp's current Haredi Chief Rabbi; synagogues that violate social distancing guidelines, fail to enforce a mask policy, and allow men who test positive to enter the synagogue (and even lead services); the medical negligence of a communal doctor who prescribes his patients antibiotics, instead of COVID tests, and spreads misinformation about the quarantine process; Hasidic groups that travel to and from their leaders in foreign countries and who forge test results to do so and to skip the mandated quarantine period. His reports indict the negligence of communal leaders, Hasidic rebbes, and a Jewish member of the City Council, who has been charged by Antwerp's governor, Cathy Beckx, to serve as the COVID-19 Jewish communal liaison.

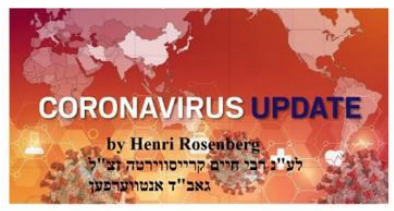

UPDATE No. 21 - August 24, 2020.

1. Today a (forbidden) wedding is being planned in Antwerp, which is contrary to the law and to Haloche. Most of the Jewish weddings from our town take place in Zaandam (100 guests inside, 250 outside, no dancing, everyone needs a seat and needs to stay seated, $1,5 \mathrm{~m}$ distancing) or London (max. 30 people).

2. In the same time a lot of Jewish Corona patients are hospitalized in Sint Vincentius and for one of them we have just been requested to pray for his recovery.

Both topics are related and the first is the cause for the second. But who cares? We are egoists and we want our wedding to go through no matter what. And let others pay the price: and, if needed $" \pi$, we will join in the prayers for recovery

\section{GK}

GOEDKOSJER - JOODSE VERBRUIKERSVERENIGING v.r.w. GOEDKOSJER - JEWISH CONSUMERS DEFENSE ASSOCIATION N.P.A. Nummer van de vereniging : $1371189 \mathrm{Nr}$ BTW of ondernemingsnr.: 440645066 -E-mail: goedkosjer@skynet.be Information often based on rumors. Updates and precisions welcome

Figure 1. Coronavirus Update. A coronavirus update by Henri Rosenberg about social distancing violations in Antwerp posted on Facebook (Source: https://www.facebook.com/media/set/?set=a. 10156927801881105\&type $=3$, accessed on 24 August 2020).

Those, like Rosenberg, who spread "gossip" and leak information to state officials about violations of public health measures, have been labelled as mosrim (informants or turncoats). ${ }^{7}$ Emboldened by communal leaders who publicly condemn mosrim, vigilantes punish turncoats for breaking these communal norms. They develop targeted campaigns 
against turncoats, using WhatsApp groups to extend their reach beyond the traditional pashkevil (a broadside) posted on a public wall. One poster that circulated in April across WhatsApp reads (Figure 2):

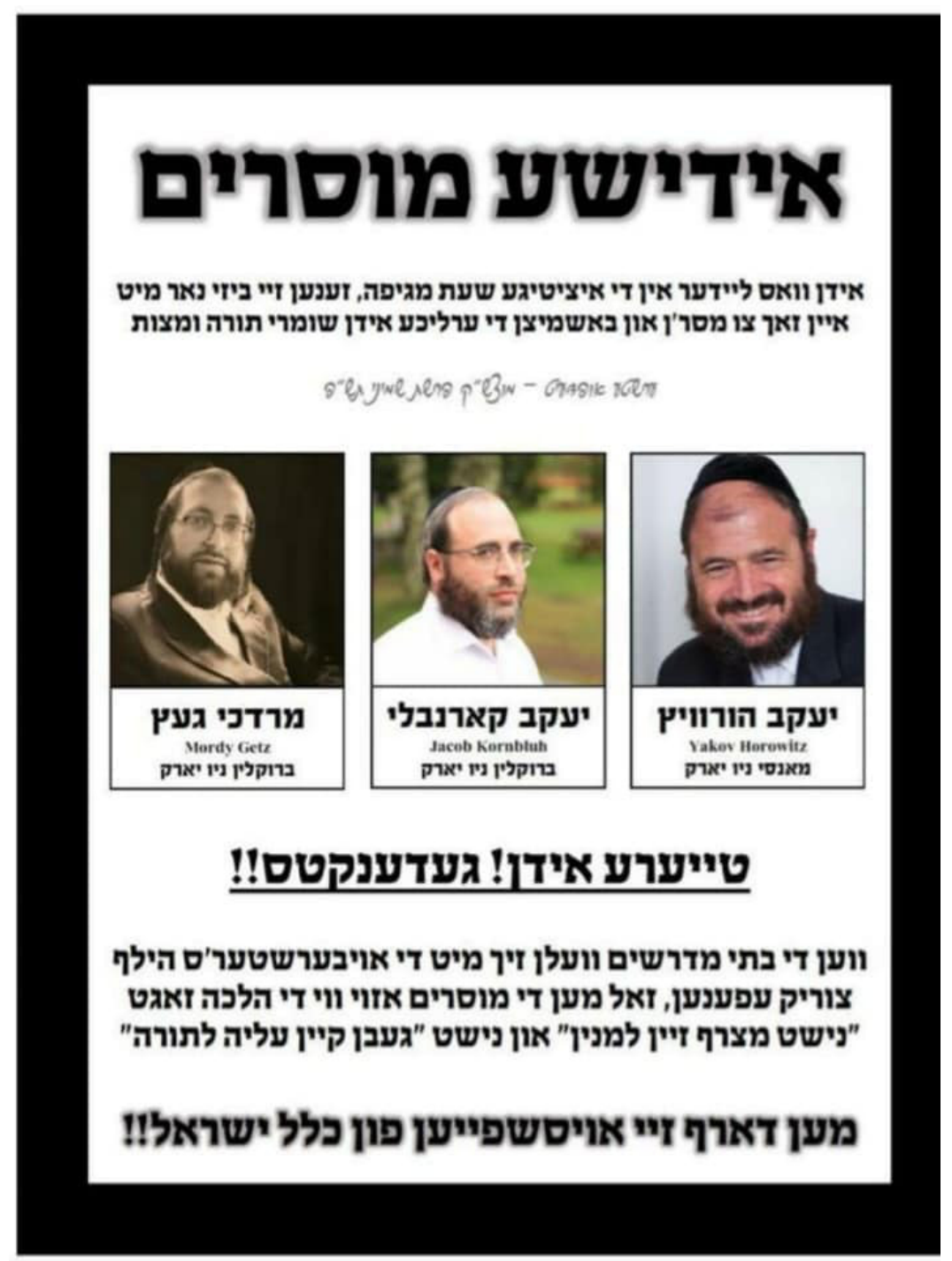

Figure 2. "Jewish Turncoats". A poster that displays the images of Jewish men who are considered "turncoats" (Source: https:/ / www.lohud.com/story/news/local/rockland/2020/04/20/socialdistancing-prayer-gatherings-orthodox-jewish-community/5164417002/, accessed on 24 August 2021).

Jewish turncoats

Jews who have unfortunately been busy in this current period of the plague only with one thing: to inform and to defame upright, religious Jews, who observe Torah and commandments.

Dear Jews! Remember!!

When the study halls/synagogues with God's help will re-open, so shall the turncoats, as Jewish Law says, "not be included in a minyan [Jewish quorum of 10 required for communal prayer]" and "not be given an aliyah to the Torah".

They need to be spit out of the Jewish people!!

While denied access to be counted within the Jewish quorum of a minyan may seem relatively innocuous, these measures amount to nothing less than social death, excommunication, and even physical harm for the accused. Indeed, on 7 October, only months after the circulation of these pamphlets, a pro-Trump mob in Boro Park cornered 
the journalist, Jacob Kornbluh, featured in the center of this poster. As Kornbluh recounted on Twitter, "I was just brutally assaulted, hit in the head, and kicked at by an angry crowd of hundreds of community members of the Boro Park protest-while yelling at me 'Nazi' and 'Hitler' - after Heshy Tischler recognized me and ordered the crowd to chase me down the street" (Chernikoff 2020).

In this space of fear and accusation, a familiar religious icon has been symbolically retooled to protect synagogues from police raids. During a visit to Belgium in January 2021, I passed three Hasidic shtieblekh (small synagogues) in Antwerp in the Jewish neighborhood where I have conducted fieldwork since 2015. Something was different. Beside official signs in Flemish that read "there is no worship until further notice" ("er is geen eredienst tot nader bericht") appeared a familiar icon (Figures 3 and 4): the portrait of the deceased Hasidic master, Reb Shayele (more formally known as Rabbi Yeshayah Steiner or The Kerestirer Rebbe). ${ }^{8}$ The icon of Reb Shayele, which can be regularly seen in storefronts and homes to protect against mice, was now visibly posted onto the front door of these synagogues..$^{9}$ Shortly thereafter, I walked to a Hasidic friend's apartment for lunch. I asked him if Reb Shayele's icon was meant to ward off the invasion of the plague itself. Rodents carry disease. The first omen of impending disaster in Albert Camus' The Plague was when thousands of rats invaded the French Algerian city of Oran, scurrying from the sewers onto the streets to meet their untimely deaths. It did not seem like a stretch, I reasoned, that Reb Shayele, fabled to ward off mice, had been symbolically extended to protect against the contemporary plague. My Hasidic friend smiled. It was sweet how naive I could be sometimes. The apotropaic magic of the amulet was intended not to ward off the plague, but rather to ward off the police. ${ }^{10}$ It was only until I looked closely at the biblical passage from the Book of Genesis above Reb Shayele's melancholic icon (one of the three texts associated with amulets Reb Shayele would distribute during his lifetime) that my friend's explanation came into clear relief: "And the people who were at the entrance of the house, young and old, they struck with blinding light, so that they were helpless to find the entrance".

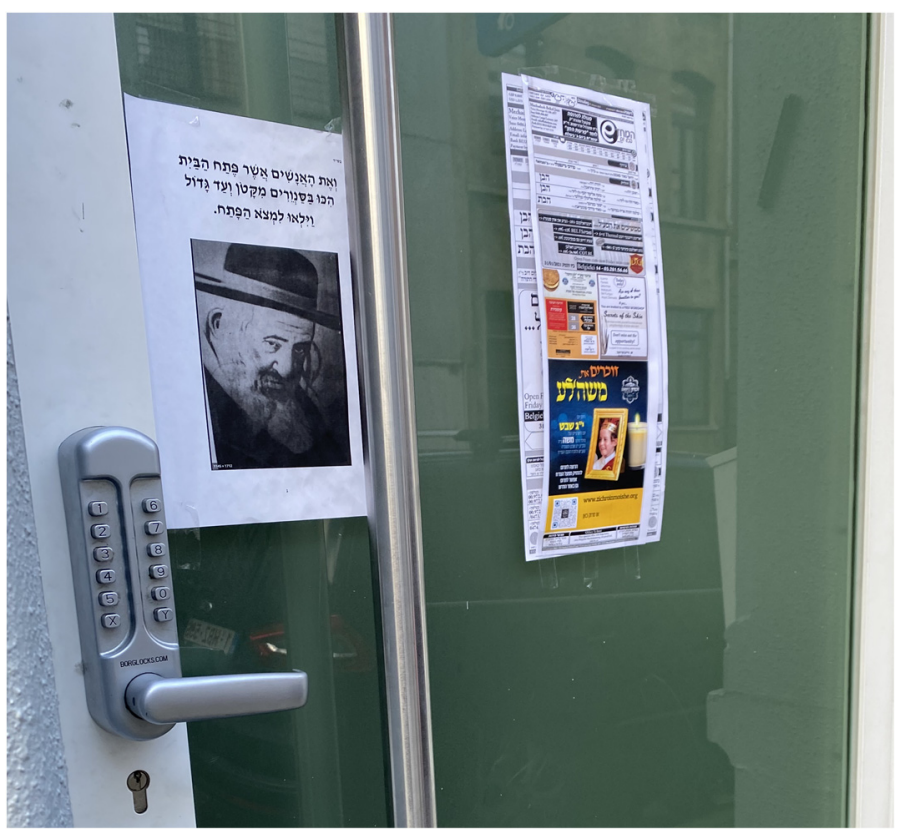

Figure 3. Reb Shayele in Antwerp. An image of Reb Shayele below a biblical verse (Genesis 19:5) on the front of a Hasidic synagogue in Antwerp (Source: photographs by author). 


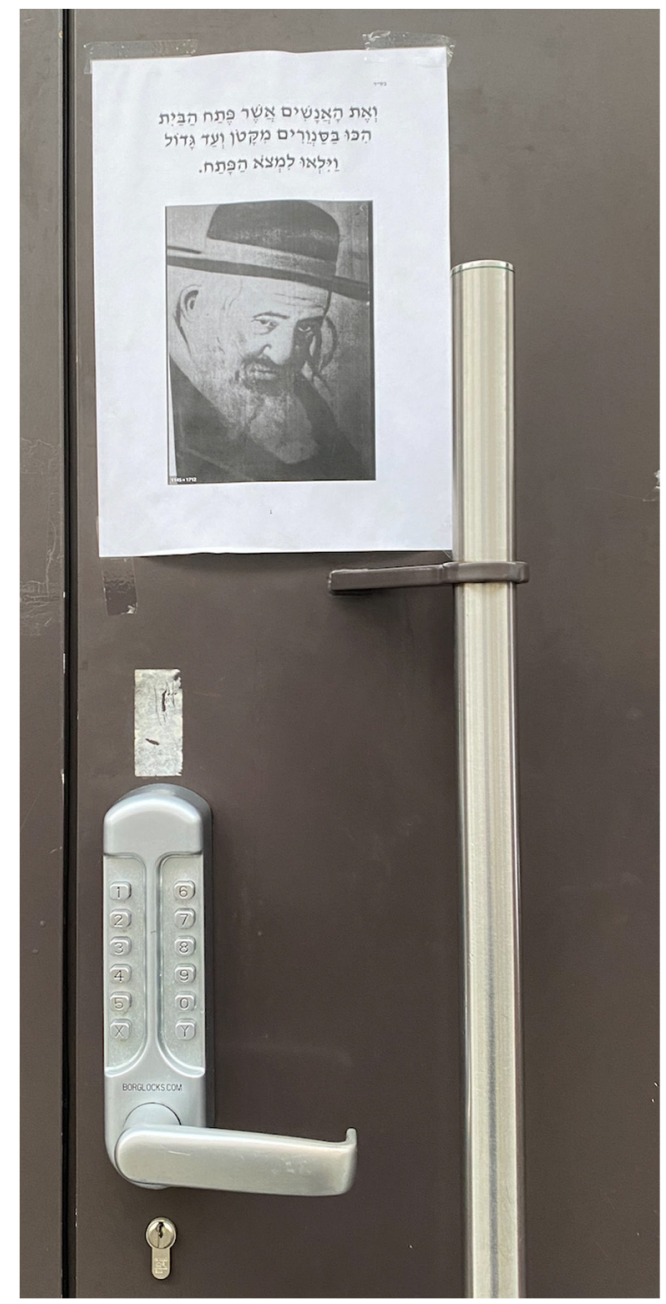

Figure 4. Reb Shayele in Antwerp. An image of Reb Shayele below a biblical verse (Genesis 19:5) on the front of a Hasidic synagogue in Antwerp (Source: photographs by author).

\section{The Political Economy of Gossip}

And yet a decidedly different understanding of the campaign comes into focus when we open the video posted on the website. ${ }^{11}$ The video opens to a series of businessmen, who speak to both their particular financial woes and the broader financial impact of the pandemic upon their communities. While visually monolithic to an outsider, the campaign is, in fact, trying to signal the "diversity" of the Haredi world (and the unity necessary to tackle the social ills of gossip). The featured men come from both different religious communities and social stations: a singer, the owner of a catering service, and the founder and CEO of an e-commerce and crowdfunding company. The video is undoubtedly normative. It only features men. ${ }^{12}$ Whether this is simply the most convenient way to appeal to the most religious audience, which censors the visibility of women, or because business is presumed to be the unique province of men, is unclear. Moreover, it only features business owners, rather than workers. While showcasing business leaders affords the campaign an air of expertise and authority, wouldn't workers themselves be best poised to speak to the precarity of this moment? And what precisely does all of this have to do with the broader campaign?

After the first $30 \mathrm{~s}$, the video cues us into the answer with a short intertitle: "where do we fit in ..." Through a testimonial genre, the businessmen explain how social media platforms are spreading rumors more virally than ever before and ruining the livelihoods of other religious business owners. "You write a comment and made you a joke about this guy, you know this guy, you make a joke with like a wink, and people build stories about 
it", the owner of a trade show design company observes. The video then turns to the CEO of a custom-designed closet company, who declares: "I've watched someone's business, from rumors about his business, completely go down ... I've watched lives get destroyed". After these testimonials, the men make their pitch to the audience, to join this campaign against spreading gossip.

A seemingly more "universal" campaign to stop the virus of gossip among Haredi Jews has now oddly taken a more particular form, one focused upon the political economy of language (Irvine 1989). The businessmen describe the clear financial impact of gossip's deleterious impact upon their communities. And in a time of increased economic uncertainty, it makes sense that this particular message would resonate. Indeed, the video offers a grounded counterpoint to the abstract, metaphysical concerns laid out in the mission statement. Collectively stopping the spread of gossip may metaphysically drive God to suspend the spread of COVID-19. Yet until divine ledger books, which tabulate individual sins and collective merits, are made open access, such acts cannot easily be witnessed (even by the faithful). Their testimonials offer grounded, relatable, and material examples of gossip's economic impact upon their communities.

The platform itself, of course, also enables them to advertise their businesses. As the businessmen tell of their financial woes, the names of their companies are conveniently listed below their own names. One of the e-mail "reminders" I received by the campaign from the "Director of Torah Projects" also included a lengthy signature block with extensive information about his commercial real estate company. To what degree is this anti-gossip campaign simply a clever way for businessowners to capitalize upon the current crisis, to secure free advertising for their companies? Who wouldn't want to buy into this form of ethical capitalism, in which morally-minded business owners pledge not to speak gossip and integrate this ethos into their corporate culture? Who, after being disarmed by the message of positivity in their video, would question their motives? After all, one should never speak ill of another Jew's business. And yet what is perhaps most striking is what is left unstated: how the campaign so explicitly acknowledges how gossip, driven by individual malice, can threaten the health of their social bonds. ${ }^{13}$

At first blush, it might be tempting to simply treat this anti-gossip campaign through a functionalist lens, that is, as only an "idiom" through which people can express or make claims about the perceived or real social fractures within their communities. This form of "metaphoric thinking" is familiar (Sontag 1978). In metaphorizing illness, the virality of COVID-19 becomes likened to the virality of gossip, to register pre-existing social anxieties and moral panic around the internet and social media. These social technologies are not only "responsible for a communal crisis of faith" (Fader 2013), but also responsible for a communal crisis of solidarity and collectivism. The likening of gossip to COVID-19 would appear to traffic in the same logic of anti-Capitalist signs (Figure 5) and graffiti (Figure 6), which diagnose COVID-19 as but a symptom of the real dis-order: Capitalism.

But this campaign is animated by something other than "metaphoric thinking". COVID-19 is decidedly not treated as unreal or less real than gossip (and its corrosive effects on society). COVID-19 is not treated as the symptom of a "real" social dis-ease plaguing Haredi communities. This campaign operates rather through a mimetic and theurgic logic. We might modify Newton's Third Law to understand this theology of social life: for every human action there is an equal and similar divine re-action. Stopping the human spread of gossip can, in turn, end the divine spread of SARS-CoV-2. 


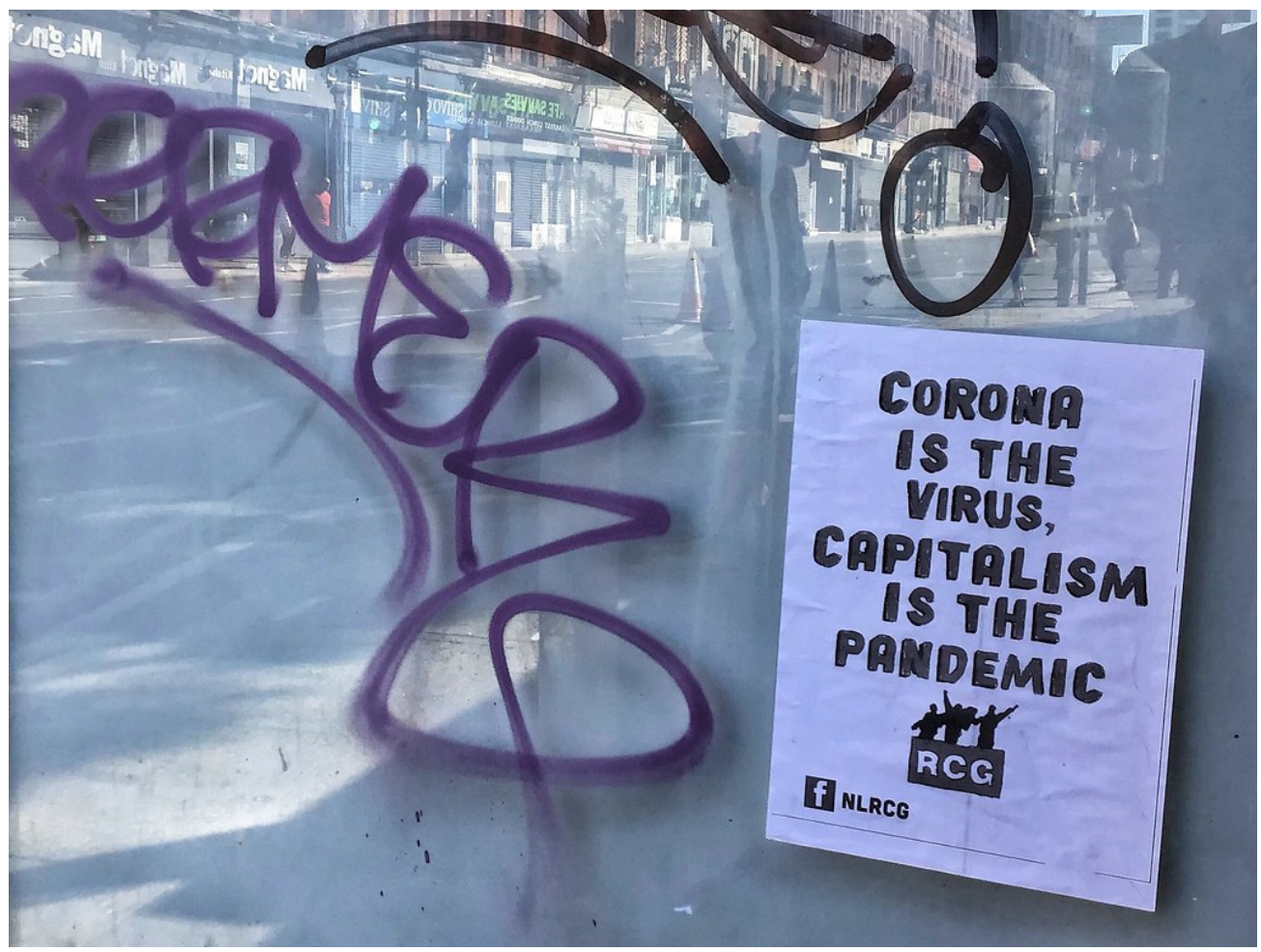

Figure 5. Anti-Capitalist Sign. An anti-Capitalist poster that frames COVID-19 as the virus and Capitalism as the pandemic (Source: https:/ / www.flickr.com/photos/8424687@N08/49953781421/, accessed on 24 August 2021).

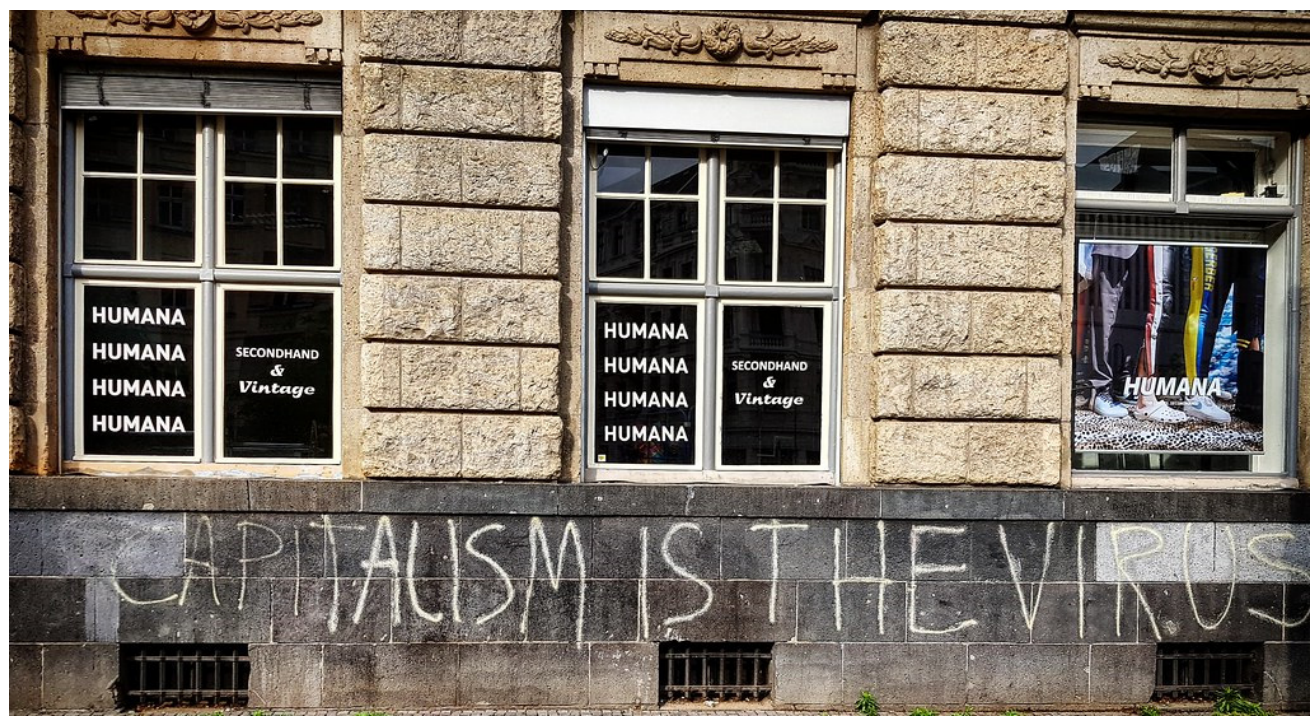

Figure 6. Anti-Capitalist Graffiti. Graffiti that frames Capitalism as the "virus"-written on the Humana Secondhand \& Vintage Shop in the Neukölln neighborhood of Berlin (Source: https: / / www.flickr.com/photos/elhamalawy/49849794112/, accessed on 24 August 2021).

\section{Conclusions}

In many respects, it is not particularly surprising that gossip has become the idee fixe of a Haredi media campaign during COVID-19. Ethical campaigns against gossip include a rich repertoire of images, songs, and texts that can be summoned and symbolically tweaked to address the particular characteristics of this historical plague. What is more intriguing is how "Stop the Spread" so explicitly addresses perceived social fractures within Haredi 
communities. Whereas scholars and social critics have largely focused on COVID-19 as a disruptive force for everyday expressions of Haredi "collectivism", the Haredi businessmen featured in this campaign anxiously and openly question the vitality of the social bonds within their respective communities.

This campaign addresses a rather circumscribed world of "insiders". It is directed at an imagined audience of (other) Haredim, who spread gossip about one another. As the male businessowners make abundantly clear, this results in both collective, spiritual ruination of their communities and financial ruination of individual businesses.

Yet as I argue, this particular media campaign must also be situated within a broader and far more coercive effort to police gossip, to prevent "insiders" from disclosing communal secrets to "outsiders". Campaigns to silence and expel mosrim ("turncoats"), who leak "insider" information about clandestine, illegal gatherings to police, index the very social frictions tearing at the seams of certain communities. By virtue of its virality, gossip can easily violate the socially prescribed boundaries between insiders and outsiders. Contrary to many dominant accounts, certain Haredi Jewish communities appear more anxious than ever about the fragility of their social bonds, as gossip spreads not only between insiders ("Stop the Spread"), but also leaks to outsiders (mosrim). This allows us to hopefully see the limitations of unreflexively valorizing religious collectivism as an antidote to the social isolation and anomie experienced under neoliberalism.

Funding: This research received no external funding.

Institutional Review Board Statement: Not applicable.

Informed Consent Statement: Not applicable.

Data Availability Statement: Not applicable.

Acknowledgments: I would like to thank Webb Keane, Amelia Frank-Vitale, Joshua Garoon, Geoffrey Hughes, Magdalena Zegarra, Yuval Katz, and Elizabeth Harlow for their incisive feedback on earlier drafts of this article. I would also like to thank Roberta Ricucci and Solange Lefebvre for their support and the three anonymous peer-reviewers for their helpful recommendations.

Conflicts of Interest: The authors declare no conflict of interest.

\section{Notes}

1 The discursive politics of naming, identifying, and grouping global religious Jewish communities is a complex matter. Many English-speaking journalists and academics simply use "Ultra-Orthodox" to assemble various Jewish communities that practice anti-assimilationist, non-liberal expressions of Judaism guided by Jewish law. This term, as others have noted, is problematic on various grounds. Certain scholars argue that it is a pejorative, "etic" term used by outsiders, rather than an "emic" term used among insiders (Goldschmidt 2006; Stolow 2010). I instead use the Modern Hebrew term "Haredi" (pl: "Haredim", lit. "those who tremble"), which is more frequently (although not uniformly) used among global religious Jewry. In this article, I largely engage with Ashkenazi Haredi Jews from Eastern and Central European backgrounds (including both Hasidic and non-Hasidic Jews).Orthodox Judaism, more broadly, can be situated historically as a product of modernity (rather than an imagined, pre-modern past) in the late 18th century. It emerged as a response to modernizing Jewish forces within western and central Europe (e.g., Reform Judaism), which places observance of Jewish law (halakha) at the center of its ideology. As Benjamin Brown notes:

the title 'Orthodox' first appears in a Jewish context in the first half of the nineteenth century, in western Europe. It was coined by opponents of Orthodoxy who compared Jewish traditionalism to a parallel phenomenon in the Christian world. Only later did Orthodox Jews themselves adopt the term. Later in the nineteenth century, the term neo-Orthodoxy was created to denote the moderate wing of Orthodoxy, which by then had emerged in Germany. In Hebrew texts up to the second half of the twentieth century the Orthodox refer to themselves as Haredim ("Men of Awe"), Yereim ("God-fearers"), or Shlomei Emunei Israel ("Israelites of Wholehearted Faith"). By the second half of the twentieth century, the latter two titles no longer denote a specific social group, while the term Haredim refers to the more extreme trend of Orthodoxy, sometimes called Ultra-Orthodoxy. (Brown 2003)

For a sophisticated theoretical account concerning the broader historical transformation of Orthodox Judaism and its "swing to the right" in the contemporary era, see Haym Soloveitchik's seminal article, "Rupture and Reconstruction" (Soloveitchik 1994). 
"the general discourse about the pandemic lumps all Ultra-Orthodox communities and their members together and labels them as Haredim. In fact, these groups cover a very wide range of ideological positions, including concerning the public's health. On the margin is the radical anti-Zionist and isolationist Neturei Karta, a religious group formally created in Jerusalem in 1938, who still sponsored crowded and unmasked marches in Jerusalem against the State of Israel in late November 2020 ... the twelve Hasidic Rabbinic 'courts' are also diverse, from that of the highly political Ger (the largest community in Israel), to the Satmar and Bobov (the largest in New York City) communities, led by inherited rabbinic leadership, to the world-wide group the Lubavitchers (world-wide under the name Chabad ... ". (Gilman 2021)

3 A certain strain of evolutionary psychology has continued in this vein. Neofunctionalists like Robin Dunbar make evolutionary claims about the utility of gossip in ways remarkably similar to Gluckman and other functionalists (Ingram 2018).

4 A similar phenomenon can be witnessed in Israel today. An anti-gossip media campaign (https://lashonhara.co.il, accessed on 20 August 2020), which pre-existed COVID-19, has taken on new life in the age of the pandemic. It appears to be sponsored by a faction within Breslev, a Hasidic sect without a living rebbe (thus known as toyte Hasidim or "dead Hasidim" in Yiddish), which has managed to adeptly reinvent itself from a small Hasidic sect persecuted by other Hasidic sects (Assaf 2010), into a neo-Hasidic, New Age revival movement (Persico 2014). As stated in the mission statement on its website, it promotes a similar anti-gossip campaign to bridge internal social fractures within Israeli society—far beyond the imagined audience of the American campaign located in Lakewood. Before COVID-19 struck, one would see billboards throughout Israel with their advertising pun: "lashon hara/lo medaber elay" ("I don't like Lashon Hara", lit: "Lashon Hara/it doesn't speak to me"). In its online promotional materials, it symbolically replaces the title given to Hassidic rebbes, "mashpia" ("a person of influence") for contemporary "influencers", trendy, non-religious, tattooed celebrities who can promote their Hasidic-cum-New-Age-universalist brand to the masses. In the wake of COVID-19, it has capitalized on the crisis of the pandemic to manufacture and sell masks with their advertising pun.

5 For a comprehensive account, which examines the complex interplay between Jewish law (halacha) and what is commonly translated as "ethics" (mussar), see Benjamin Brown's "From Principles to Rules and from Musar to Halakhah-The Hafetz Hayim's Rulings on Libel and Gossip" (Brown 2008).

6 In Yiddish-speaking Haredi communities, a children's nursery rhyme captures the severity of this sin and places the burden on each child to remember its severity. This disrupts an impulse to fetishize gossip — that is, to afford it animacy, to spread and multiply on its own accord (like money), without agents who actively elect to participate in its dissemination. The nursery rhyme below treats children as agentive, with sufficient ability to understand the severity of their actions (translation is my own):

"Sha sha sha!/Nisht redn loshen hure/Oy vay vay vay/Vos far a tsure/Nisht redn loshen hure/In keyn Yiddish hoyz/Di aveirah iz zayer, zayer groys/Ale kinderlekh fun groys biz kleyn/Darfn dos gedenken aleyn"

“Shhh shhh shhh!/Don't speak gossip/Oy vay vay vay/What an affliction/Don't speak gossip/In every Jewish home/The sin is very, very great/All children from big to small/Need to remember this for themselves"

7 Saul Berman meticulously describes the multivalence of the term and its historical evolution. He describes how the term bears a "double-meaning". The Moser refers to "distinctive criminal disloyalty of handing over an innocent Jew to a non-Jewish or Jewish oppressive authority or criminal who would subject him to unjust treatment involving confiscation of his property and possible taking of his life. But as a general ethical term, the word Moser was used to describe any undesirable manifestation of disloyalty to a fellow Jew involving 'snitching' to any authorities" (Berman 2016).

For more information about mosrim and COVID-19, see recent work published by the criminologist, Dikla Yogev, concerning cooperation between Israeli Haredim and the police. I have borrowed her translation of mosrim as "turncoats" in this article. (Yogev 2021).

8 This interpretation is substantiated in an article on the Haredi news website, Behadrei Haredim, which documents what I observed in Antwerp. I apparently was not the only one perplexed by Reb Shayele's appearance. An one Jewish man recounted, with a smile, how one of his non-Jewish neighbors approached him the week before. The neighbor was concerned. Had they found the missing person whose picture had been posted around the neighborhood? If not, perhaps they could publish his picture in the newspaper? (Weisberg 2020).

9 This Hungarian miracle-worker, who lived and died in Bodrogkeresztúr, Hungary (1851-1925), occupies a peculiar, if not singular, position in the pantheon of Jewish patron saints. He is the patron saint of protection. There are different tales concerning the origin of this association. In one version, a man visited Reb Shayele at his home one Saturday night, when the Hasidic master would famously host a weekly celebratory meal after the Sabbath's conclusion (melave malka). The man's livelihood had been all but ruined by mice, who had eaten the provisions in his warehouse. Reb Shayele asked the man if his Christian pastor treated the local Jews well. When the man responded in the negative, Reb Shayele told the poor man to return to his warehouse and instruct the mice to seek vengeance on the local pastor. The mice complied with these orders. Reb Shayele miraculously managed to both save this poor man's livelihood and punish the local Christian pastor (in other versions, it was a nobleman). This version highlights many of the iconic traits associated with Reb Shayele: his hospitality and protection against misfortune, particularly against the infestation of vermin (Swart 2017).

The presence of Reb Shayele's amulet is polysemic. Haredi homeowners and businesspeople may hang Reb Shayele's amulet simply to ward off mice. His icon may also signify the presence of illicit behaviors or shady business practices, however. Real 
estate owners may hang his amulet in a construction site to ward off inspection agents or drivers may hang his amulet in their car windows to protect them from parking tickets (e.g., blocking a fire hydrant) (Gruntig 2017). His icon also appeared to ward off governmental authorities during the measles outbreak among Haredi Jews in 2018-2019 in the United States.

10 This passage is drawn from the famous story of Sodom and Gomorrah, often misinterpreted and (anachronistically) cited as a prooftext against "homosexual" acts of sodomy, despite early rabbinic commentaries that interpret it as a tale that showcases the evils of inhospitality and greed (Greenberg 2004). In the story, Abraham's nephew, Lot, refuses to comply with the demands of the Sodomites, who wish to rape his male guests (who are, in fact, two angels disguised as humans). Despite Lot's disturbing counteroffer, his two daughters, the men of Sodom attempt to break down Lot's door. God, in turn, blinds the angry mob.

11 Video link: https:/ / res.cloudinary.com/dyuuf6gor/video/upload/v1584563898/StopTheSpread/Video.mp4_ikboug.mp4 (accessed on 26 March 2020).

12 This particular campaign does not castigate women as the culprits of gossip. It presents gossip as a problem plaguing the wider community. This is significant as "gossip" should not be taken as self-evident nor assumed to hold as a stable, universal category. Particular gender and language ideologies determine under what conditions talk is characterized as gossip. As linguistic anthropologist Niko Besnier has noted, "in many societies, furthermore, what counts as gossip is subject to different interpretations among social groups. Gender is one dimension of social difference and inequality that is a particularly common parameter of disagreement about what counts as gossip" (Besnier 2019). Men might valuate their own talk in favorable terms, yet devalue the very same talk when spoken by women as "gossip". Besnier quotes an illustrative passage from F.G. Bailey's ethnographic observations of the southern French valley in the 1960s: "men's gossip is called 'bavarder: a friendly, sociable, light-hearted, good-natured, altruistic exchange of news, information and opinion. But if women are seen talking together, then something quite different is happening: very likely they are indulging in mauvaise langue—gossip, malice, character assassination'" (Besnier 2019).

13 The drive to draw parallels or homologies between the virality of COVID-19 and the virality of gossip is certainly not unique to this campaign, however. During the Angelus Prayer on 6 September 2020, Pope Francis addressed the faithful from his balcony. Departing from a prepared text, he explained that "the great gossiper is the devil, who always goes about telling bad things about others, because he is the liar who seeks to separate the Church to distance brothers and sisters and not create community. Please, brothers and sisters, let us make an effort not to gossip. Chatter is a plague more awful than COVID! Let us make an effort: no gossip" (Francis I 2020).

\section{References}

Anderson, Kay J. 1987. The Idea of Chinatown: The Power of Place and Institutional Practice in the Making of a Racial Category. Annals of the Association of American Geographers 77: 580-98. [CrossRef]

Assaf, David. 2010. Untold Tales of the Hasidim. Translated by Dena Ordan. Waltham: Brandeis University Press.

Avishai, Orit, Ayala Fader, and Lea Taragin-Zeller. 2020. Why Are Some Ultra-Orthodox Jews Flouting Social Distancing Rules? New York Daily News. April 8. Available online: https:/ / www.nydailynews.com/opinion/ny-oped-why-some-jews-flouting-rules-20 200409-u6jetgi4ubgtxla4oindag37gy-story.html (accessed on 18 August 2020).

Berman, Saul. 2016. Boundaries of Loyalty: Testimony Against Fellow Jews in Non-Jewish Courts. Cambridge: Cambridge University Press. Besnier, Niko. 2009. Gossip and the Everyday Production of Politics. Honolulu: University of Hawaii Press.

Besnier, Niko. 2019. Gossip in Ethnographic Perspective. In The Oxford Handbook of Gossip and Reputation. Oxford: Oxford University Press.

Brown, Benjamin. 2003. Orthodox Judaism. In The Blackwell Companion to Judaism. Edited by Jacob Neusner and Alan J. Avery-Peck. Malden: Blackwell Publishers. [CrossRef]

Brown, Benjamin. 2008. From Principles to Rules and from Musar to Halakhah: The Hafetz Hayim's Rulings on Libel and Gossip. Dine Israel: An Annual of Jewish Law and Israeli Family Law 25: 171-256.

Chernikoff, Helen. 2020. Orthodox Journalist Attacked, Chased, Called 'Nazi' at Jewish Borough Park Protest. The Forward. October 7. Available online: https://forward.com/fast-forward/456050/orthodox-journalist-attacked-chased-called-nazi-at-jewishborough-park/ (accessed on 15 February 2021).

Douglas, Mary. 1966. Purity and Danger: An Analysis of Concepts of Pollution and Taboo. New York: Praeger.

Durkheim, Émile, Steven Lukes, and Wilfred Douglas Halls. 2014. The Division of Labor in Society. New York: Free Press.

Fader, Ayala. 2009. Mitzvah Girls: Bringing Up the Next Generation of Hasidic Jews in Brooklyn. Princeton: Princeton University Press.

Fader, Ayala. 2013. Neoliberal Jewish Women's Audiocassette Lectures in Brooklyn: A Crisis of Faith and the Morality of Media. American Anthropologist 115: 72-84. [CrossRef]

Francis I. 2020. Angelus. Available online: https://press.vatican.va/content/salastampa/en/bollettino/pubblico/2020/09/06/20090 6a.pdf (accessed on 27 October 2021).

Gilman, Sander L. 2021. Placing the Blame for COVID-19 in and on Ultra-Orthodox Communities. Modern Judaism-A Journal of Jewish Ideas and Experience 41: 1-30. [CrossRef]

Gluckman, Max. 1963. Papers in Honor of Melville J. Herskovits: Gossip and Scandal. Current Anthropology 4: 307-16. Available online: https:/ / www.jstor.org/stable/2739613 (accessed on 23 September 2021). 
Goldberger, Frimet. 2020. The Challenge of Social Distancing in Hasidic Communities. The New York Times. April 9. Available online: https:/ / www.nytimes.com/2020/04/09/opinion/hasidic-jews-COVID-distancing.html (accessed on 18 August 2020).

Goldschmidt, Henry. 2006. Race and Religion Among the Chosen People of Crown Heights. New Brunswick: Rutgers University Press.

Greenberg, Steven. 2004. Wrestling with God and Men: Homosexuality in the Jewish Tradition. Madison: The University of Wisconsin Press.

Greenberg, Yitz. 2020. Coronavirus and the Haredim. The Jerusalem Post. April 22. Available online: https://www.jpost.com/opinion/ coronavirus-and-the-haredim-opinion-625527 (accessed on 18 August 2020).

Gruntig. 2017. Segulah for Protection Against Parking Tickets? Gruntig. June 9. Available online: http://www.gruntig.net/2017/06/ segulah-for-protection-against-parking.html (accessed on 24 August 2021).

Gupta, Akhil, and James Ferguson. 1992. “Beyond 'Culture': Space, Identity, and the Politics of Difference. Cultural Anthropology 7: 6-23. [CrossRef]

High, Casey, Ann H. Kelly, and Jonathan Mair. 2012. Introduction: Making Ignorance an Ethnographic Object. In The Anthropology of Ignorance: An Ethnographic Approach. New York: Palgrave MacMillan, pp. 1-32.

Hoffman, Yair. 2020. New Corona Health Letter from Rav Chaim Kanievsky and Rav Gershon Edelstein. The Yeshiva World. March 15. Available online: https:/ / www.theyeshivaworld.com/news/headlines-breaking-stories/1840119/new-corona-health-letterfrom-rav-chaim-kanievsky-and-rav-gershon-edelstein.html (accessed on 9 August 2021).

Hughes, Geoffrey, Megnaa Mehtta, Chiara Bresciani, and Stuart Strange. 2019. Introduction: Ugly Emotions and the Politics of Accusation. The Cambridge Journal of Anthropology 37: 1-20. [CrossRef]

Ingram, Gordon P. D. 2018. Gossip. In The International Encyclopedia of Anthropology. Edited by Hilary Callan. Hoboken: John Wiley \& Sons. [CrossRef]

Irvine, Judith. 1989. When Talk Isn't Cheap: Language and Political Economy. American Ethnologist 16: 248-67. [CrossRef]

Jaskoll, Shoshana-Keats. 2020. What Is the Gematria of 'Witch Trials'? The Times of Israel. April 1. Available online: https://blogs. timesofisrael.com/what-is-the-gematria-of-witch-trials/ (accessed on 18 August 2020).

Kravel-Tovi, Michal, and Esra Özyürek. 2020. Contagious Crowds: Religious Gatherings in the Age of Coronavirus. LSE COVID-19 Blog. May 22. Available online: https://blogs.lse.ac.uk/COVID19/2020/05/22/contagious-crowds-religious-gatherings-in-theage-of-coronavirus/ (accessed on 8 November 2020).

Laidlaw, James. 1995. Riches and Renunciation: Religion, Economy, and Society Among the Jains. Oxford: Oxford University Press.

Lewis, Justin Jaron. 2015. Vocal Exuberance and Social Engineering: Gossip in Hafetz Hayim. Studies in religion. Sciences Religieuses 44: 208-32. [CrossRef]

Merry, Sally Engle. 1984. Rethinking Gossip and Scandal. In Toward a Theory of Social Control, Volume I: Fundamentals. Edited by Donald Black. Orlando: Academic Press.

Mintz, Jerome R. 1998. Hasidic People: A Place in the New World. Cambridge: Harvard University Press.

Paine, Robert. 1967. What is Gossip About? An Alternative Hypothesis. Man 2: 278-85. [CrossRef]

Palmer, Ewan. 2020. Orthodox Jews Set Fire to Masks in Protest at New York's COVID Restrictions. Newsweek. October 7. Available online: https: / / www.newsweek.com/orthodox-jews-mask-protest-new-york-1536946 (accessed on 18 August 2020).

Persico, Tomer. 2014. Neo-Hasidic Revival: Expressivist Uses of Traditional Lore. Modern Judaism: A Journal of Jewish Ideas and Experience 34: 287-308. [CrossRef]

Rubin, Israel. 1972. Satmar: An Island in the City. Chicago: Quadrangle Books.

Soloveitchik, Haym. 1994. Rupture and Reconstruction: The Transformation of Contemporary Orthodoxy. Tradition 28: 64-130. Available online: https:/ / www.jstor.org/stable/23261215 (accessed on 23 September 2021).

Sontag, Susan. 1978. Illness as Metaphor. New York: Farrar, Straus, and Giroux.

Spivak, Gayatri. 1993. In a Word: Interview. In Outside in the Teaching Machine. New York and London: Routledge, pp. 1-26.

Steinsaltz, Adin. 2019. Vol. 40 Arakhin, Temura_Large the Koren Talmud Bavli Noé. Jerusalem: Shefa Foundation, Available online: https: / / www.sefaria.org/Arakhin.15b.11?lang=en (accessed on 23 August 2021).

Stolow, Jeremy. 2010. Orthodox by Design: Judaism, Print Politics, and the Artscroll Revolution. Berkeley and Los Angeles: University of California Press.

Swart, Jacobus G. 2017. The Book of Seals \& Amulets. Gauteng: The Sangreal Sodality Press.

Weisberg, Moshe. 2020. Bate hakneset kosu btemunat hatsadik uma shaal hagoy? [The Synagogues Were Covered with the Image of the Saint and What did the Gentile Ask?]. Behadrei Haredim. December 30. Available online: https://www.bhol.co.il/news/1170085 (accessed on 23 August 2021).

Wolf, Eric. 1982. Europe and the People Without History. Berkeley and Los Angeles: University of California Press.

Yogev, Dikla. 2021. Community-Society Equilibrium: Religious Organizations in the Service of the Secular State. Contemporary Jewry, 1-18. [CrossRef] [PubMed] 